\title{
Nondenaturing Procedure for Rapid Preparation of Ferredoxin from Clostridium pasteurianum ${ }^{1}$
}

\author{
STEPHEN G. MAYHEW \\ Deparment of Biological Chemistry, The Universily of Michigan, \\ Anu Arbor, Michigan 8104
}

Received November 6. 1970

Lovenberg and Williams (1) have reported that, when a solution of Clostridium pasteurianum ferredoxin in $90 \%$ ammonium sulfate is treated on a column of DEAE-cellulose, ferredoxin is retained by the column. They showed that ferredoxin is eluted when the ammonium sulfate concentration is lowered to about $35 \%$ saturation. These observations suggested the method described in this paper for purifying ferredoxin from crude extracts of $C$. pasteurianum. This novel procedure provides pure ferredoxin in yields comparable with those obtained using a method described earlier by Mortenson (2). Since it avnids the strongly denaturing conditions that occur during the initial acetone fractionation of Mortenson's method (2), this procedure may be especially useful when other proteins are to be prepared from the same starting material.

\section{MATERIALS AND METHODS}

Clostridium pasteurianum (American Type Culture Collection 6013) was grown with ammonium sulfate as nitrogen source on the medium of Carnahan and Castle (3). Cells were harvested with a Sharples super centrifuge, and dried in a vacuum, over $\mathrm{H}_{2} \mathrm{SO}_{4}$ at room temperature. Dried cells were ground to a fine powder and stored at $-20^{\circ}$. Peptostreptococcus elsdenii (strain LC 1) was grown in iron-rich medium; ferredoxinfree extracts from this organism were prepared as deseribed previously (4). Ferredoxin was assayed by measuring its stimulation of acetyl phosphate production from pyruvate by a ferredoxin-free extract from $P$. elsdenii (4). Fxtracts from $P$. elsdenii were used for this assay because they are more stable than similar (xtracts from $($. pasteurianum (5). Iron was determined according to Massey (6). For DEAE-cellulose chromatography, Whatman D) Fi22 was lesed. Ammonium sulfate (enzyme grade) was from Mann. Before application to a column of IDEAE-cellu-

'Supported by a grant from the It. S. Publie: Health servied (ciN 11106) to Dr. I. Massey. 
lose, solutions of ammonium sulfate were freed of dissolverl gases by evacuation at a water pump.

\section{RESULTS AND DISCLSSIOA}

The starting material for this procedure is $45 \mathrm{gm}$ of dry cells of $C$. pasteurianum. The cells are extracted by autolysis in $450 \mathrm{ml}$ of water at $30^{\circ}$ for $1 \mathrm{hr}$ under a nitrogen atmosphere. All subse(puent operations are done at $4^{\circ}$. Cell debris is removed from the extract by centrifugation $(25,000 \mathrm{~g}$ for $30 \mathrm{~min})$ and resuspended in $450 \mathrm{ml}$ of water. This mixture is centrifuged again, and the supernatant adderl to the initial extract.

The combined extracts are adjusted to $0.1 . M$ Tris- $\mathrm{HCl}, \mathrm{pH} 7.6$, by addition of $0.5 \mathrm{M}$ Tris-HCl buffer, $\mathrm{pH}$ 7.6. Solic ammonium sulfate is added slowly to this solution to $55 \%$ saturation and after stirring for $15 \mathrm{~min}$ a precipitate is removed by centrifugation $(25,000 \mathrm{~g}$ for $20 \mathrm{~min})$ and discarded. The amber colored supernatant is applied to a column of DEAE-cellulose $(25 \times 2$ cm diameter 1 equilibrated with $55 \%$ ammonium sulfate and $0.1 M$ Tris-HCl buffer, $\mathrm{pH}$ 7.6. Ferredoxin is retained at the top of the column in a black bant. The column is washed with $500 \mathrm{ml}$ of $40 \%$ ammonium sulfate in $0.1 . M$ Tris-HCl buffer, $\mathrm{pH}$ 7.6. This strips a yellow band from the column, and slowly elutes a red colored band that contains rubredoxin (7). The column is then washed with $30 \%$ anmonium sulfate in $0.1 \mathrm{M}$ Tris- $\mathrm{HCl}, \mathrm{pH} \mathbf{7 . 6}$, to elute ferredoxin as a brown

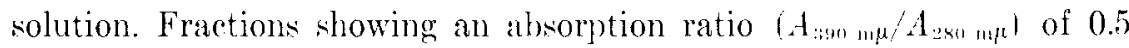
or greater are combinel.

The combined fractions are placed in a Büchner flask and solid ammonium sulfate is added in about six portions to $60 \%$ saturation. After cach addition of ammonium sulfate, and before stirring the mixture to dissolve the salt, the flask is evacuated at a water pump and filled with nitrogen. This precaution is taken to minimize losses of ferredoxin due to exposure to air. The solution is stirred for $30 \mathrm{~min}$ after the final addition of ammonium sulfate, centrifuged $(20,000 \mathrm{~g}$ for $10 \mathrm{~min})$, and the precipitate is rliscarder. The supernatant is applierl to a second column of DEAEcellulose equilibrated with $60 \%$ ammonium sulfate in $0.1 \mathrm{M}$ Tris-HCl, bH 7.6. The column is washed with $30 \%$ ammonium sulfate in $0.1 M$ Tris$\mathrm{HCl}, \mathrm{pH}$ 7.6. This first elutes traces of rubredoxin and other contaminating proteins, and then elutes ferredoxin. Brown fractions with an absorption ratio $\left(A_{: 39 \mathrm{~m} \mu /} / A_{2 \times 0 \mathrm{~m} \mu}\right)$ of 0.82 are combined. Ferredoxin is precipitated from this solution by addlition of solid ammonium sulfate to $100 \%$ saturation. This step is curried out in a Büchner flask under a nitrogen atmosphere as described above. The mixture is centrifuged $\{20,000 \mathrm{~g}$ for $15 \mathrm{~min})$ and the black precipitate is diswolved in 0.1 TrisIII' 'I, PII 7.6. 
TABIL', I

Purification of ( $\therefore$ pastemianum Fertedoxin

\begin{tabular}{|c|c|c|c|c|c|}
\hline Purification step & $\begin{array}{c}\text { Volume } \\
\text { ml }\end{array}$ & $\begin{array}{l}\text { Tutal } \\
\text { activily } \\
\text { unit: }\end{array}$ & Yield, r. & $A_{3:(111, \mu}$ & $\begin{array}{l}A_{3: 11 \mathrm{~m} \mu,} \\
A_{: 0 \mathrm{~m} \mu}\end{array}$ \\
\hline Crude extract ${ }^{\prime}$ & $6 \times 5$ & 2860 & 100 & - & 一 \\
\hline First DLAC-cellulose oblum! & 218 & 2740 & 96 & 0.71 & 0.55 \\
\hline Second I)EAE-cellulose column & 169 & 1720 & 60 & 0.49 & 0.82 \\
\hline$\left(\mathrm{NH}_{4}\right)_{2} \mathrm{SO}_{4}$ precipitate & 7.4 & $16 ; 0$ & 57 & $11.5^{h}$ & 0.82 \\
\hline
\end{tabular}

"The starting material was 45 gm of dry cells.

${ }^{b}$ Determined on a sample diluted 10-fold into 0.1 M Tris-HCl, pH 7.6.

Details of this procedure are given in Table 1 . The data show that about $60 \%$ of the ferredoxin in the initial extraet is recovered in the final ammonium sulfate precipitate. The yiedt of ferredoxin is thus comparable with yields obtained using the procedure deseribed by Mortenson (2). In

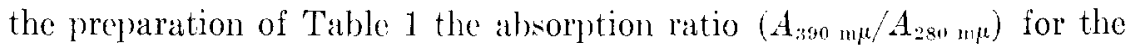
ferredoxin from the first I)EAE-collulose colum was 0.55 . In other preparations, this ratio was as high as 0.81 . However, in these preparations the cells were extracted only once, and the ferredoxin in the extract was about $20 \%$ lower than in the extract of Table 1 . Protein was not estimated during this preparation beratuse colorimetric determinations bascd on the biuret reaction are known to be unreliable when they are used to determine ferredoxin $(2,5)$. Howerer, based on a specific extinction coefficient of 34 at $390 \mathrm{~m} \mu$ (5), the total ferredoxin obtained in this preparation was $25 \mathrm{mg}$.

The absorption spectrum of ferredoxin isolated by this procedure is similar to that reported by Lovenberg et al. (5) and by Mortenson (2) for ('. pasteurianum ferredoxin. It shows absorption maxima at 385$390 \mathrm{~m} \mu, 300 \mathrm{~m} \mu$, and $285 \mathrm{~m} \mu$. The maxima at 300 and $285 \mathrm{~m} \mu$ have equal intensity; the minimum between them oceurs at $293 \mathrm{~m} \mu$. The absorption

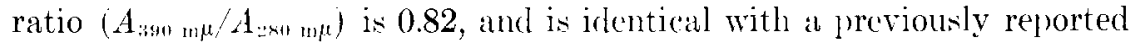
value for (. pasteurianum ferrerloxin (5). Analyses for total nonheme iron $(6)$ in a sample of ferredoxin made by this new method showed that the extinction coefficient per iron is $3840 \mathrm{M}^{-1} \mathrm{~cm}^{-1}$ at $390 \mathrm{~m} \mu$. Several values have been reported for the molar extinetion coefficient of $(2$. pasteurianum ferredoxin at this wavelength (e.g., 2, 8, 9). Based on the highest value reported $\left(30,000 \mathrm{M}^{-1} \mathrm{~cm}^{-1}(8)\right)$ the present iron analyses indieate that the preparation contained 7.8 atoms of iron per molecule. This value is in substantial agreement with the 7 iron atoms per molecule of ${ }^{*}$. pasteurianum ferredoxin reported by Lovenberg et al. (5), and it is the same as the iron content recently rejorted for Clostridium acidiurici 
ferredoxin by Hong and Rabinowitz (10). In an extensive investigation, Hong and Rabinowitz 110) determined an extinction cocffeient of

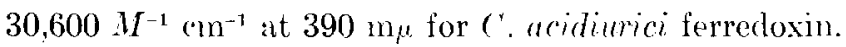

This procedure offers certain anvantages over other methods which have been used to prepare ( 2 . pasteurianum ferredoxin $(2,5)$. Ferredoxin can be prepared rapidly and in high yield, and since all of the fractionation steps are relatively mild other proteins may be prepared from the same starting material.

The phenomenon by which ferredoxin is retaince on DFAE-cellulose in roncentrated ammonium sulfate is not completely understood. However, it seems unlikely that ionic bonding with DEAE-cellulose is involved; positively charged proteins such as ribonuclease and horse heart cytochrome $c$ also show this behavior. This phenomenon is discussed in greater detail in another paper (11).

\section{SUMMARY}

A procedure is described for the rapid preparation of ferredoxin in high yield from crude extracts of $C^{\prime}$. pastevrianum. The method involves two successive chromatographic treatments on DEAE-cellulose in concentrated ammonium sulfate. Ferredoxin prepared by this method has an absorption spectrum and iron content similar to forredoxin prepared by other methods.

\section{REFERENCES}

1. Lovenberg, W., axil Williams, W. M., Biochemistry 8, 141 (1969).

2. Mortensox, I. E., Biochim. Biophyx. Acta 81, 71 (1964).

3. Carnahan, J. E., añu Castile. J. E.. J. Bacleriol. 75, 121 (1958).

4. Mayhew, S. G. and Massex, V.. J. Biol. Chem. 244, 794 (1969).

5. Iovenberg, W., Buchanan, B. B., and Rabinowitz. J. C.. J. Biol. Chem. 238, 3899 (1963).

6. Massey, V., J. Biol. (hem. 229, 763 (1957).

7. Lovesberf, W., and Sobel, B. E., Proc. Natl. Acal. Sci. U. S. 54, 193 (1965).

8. Sobei, B. F.. Axp Lovenberg, W., Biochemistry 5, 6 (1966).

9. Maynew. S. G.. Petering. D., Paimer, G., axd Fouser, G. P., J. Biol Chem. 244, $2830(1969)$.

10. Hong, J.-S., and Rabinowitz, J. C.. J. Biol. Chem. 245, 4982 (1970).

11. Maynew, s. G., axd Howell. I. G., Anal. Biochem., 41, 466 (1971). 